published). Streptozotocin is also more toxic for microorganisms in concentrations which elicit a mutagenic response.

More striking, however, are the pharmacological differences. We have shown that with streptozotocin, microbial mutagenic activity is present in blood and urine and is detectable soon after injection. The fact that NG and dimethylnitrosamine were negative in the blood-plate test but were mutagenic in the standard host-mediated assay lends credibility to the principle of the latter test.

The detection of streptozotocin-related mutagenic activity in the blood, and allied data, indicates that this compound could be a useful standard mutagen. Results obtained from the blood tests, although not as complete or quantitative as the host-mediated data, also suggest a potential screening technique for physiologically active mutagens in which fluid or tissue samples can be used in conjunction with standard plate tests.

We thank Mrs Holdine Roginski for help with photography and Dr Bruce Ames for supplying the Salmonella culture.

Cell Biology Branch,

M. G. GABRIDGE

A. Denunzio

M. S. Legator

Bureau of Science,

Food and Drug Administration,

Washington.

Received Octobcr 28, 1968.

${ }^{1}$ Evans, J., Gerritsen, G., Mann, K., and Owen, S., Cancer Chemotherapy Rep., 48, 1 (1965).

'Sugimura, T., and Fujimura, s., Nature, 216, 943 (1967).

Arison, R., and Feutale, E., Nature, 214, 1254 (1967).

4 Price, K., Buck, R., and Lein, J., Antimicrobial Agents and Chemotherapy, $505(1964)$

s Kolbye, S., and Tegator, M. S., Mutation Res. (in the press).

'Sokolski, W., Vavra, J., and Hanka, L., Antibiot. Ann., 240 (1959-60).

"Herr, R., Jahnke, H., and Argoudelis, A., J. Amer. Chem. Soc., 89, 4808 (1967).

${ }^{8}$ Cerda-Olmeda, E., and Hanawalt, D., Biochim. Biophys. Acta, 142, 450 (1967).

\section{Paternal versus Maternal Inactivation in the $X$ Chromosome of Female Mice}

Evans et al. ${ }^{1}$ have shown that a "late labclling" $X$ chromosome occurs in normal somatic cells of the mouse. Using fermale mice, heterozygous for the Cattanach translocation, in which an autosomal segment is inserted into an $X$ chromosome making the translocated chromosome $\left(X^{t}\right)$ recognizable as the longest member of the complement ${ }^{2}$, they showed that this abnormally long chromosome was "hot" in about half the cells that contained a late-labelling chromosome. In the remaining cells, the hot chromosome was always one of the long chromosomes and was presumed to be the $X^{\mathrm{n}}$ chromosome. These observations were interpreted as supporting evidence for the postulate of random inactivation ${ }^{3}$ of the maternal and paternal $X$ chromosomes.

Recognition of the normal $X$ chromosome in the mouse is, however, difficult because it falls within the size range of the longest autosomes and cannot be distinguished from them in cells where several chromosomes are almost equally late-labelling. In viow of those difficulties, wo considered it worthwhile to repeat the labelling experiment of Evans et al. ${ }^{1}$ on female mice in which the Cattanach- $X$ ehromosome was known to be inherited either from the mother or from the father. In such females, the easily recognizable $X^{t}$ can always be identified as the maternal or paternal $X$ and it is possible to test whether its parental origin is relevant to its labelling behaviour.

In a preliminary experiment, female mice were killed at intervals of $2,2 \cdot 5,3$ and $3 \cdot 5 \mathrm{~h}$ after a single intraperiton- eal injection of tritiated thymidine in order to establish the time at which approximately 40 per cent of all metaphases in femoral bone marrow suspensions were labelled. In this way, it was hoped to obtain a narrow cohort of cells labelled late in tho $\mathrm{S}$-period.

On the basis of the results obtained from this preliminary experiment, two female mice heterozygous for a maternal $X^{t}$ and two female mice heterozygous for a paternal $X^{\mathrm{t}}$ (age 3 months) were injected intraperitoneally with $0.5 \mathrm{ml}$. of tritiated thymidine (specific activity $22 \mathrm{Ci} / \mathrm{mM}$ total activity $200 \mu \mathrm{Ci}$ per mouse) and killed $2.5 \mathrm{~h}$ later. $1.5 \mathrm{~h}$ before killing, each mouse was injected intraperitoneally with 0.04 per cent of colchicine in $\mathrm{N}$ saline (volume injected $0.01 \mathrm{ml} . / \mathrm{g}$ body wt.). Coll suspensions of femoral bone marrow were prepared in hypotonic ( 1 per cent) sodium citrate. The cells were fixed in $3: 1$ (abs. acetic) stained in carbol fuchsin ${ }^{4}$ and filmed with Kodak $A R 10$ stripping film. The autoradiographs were exposed for 3 weeks at $4^{\circ} \mathrm{C}$.

Table 1. FREQUENCY OF CELLS CONTAINING A HOT $\boldsymbol{X}^{\mathrm{L}}$ OHROMOSOME IN BONE MARROW CELIS OF FEMATE MIOF KILLED $2 \cdot 5$ H AFTER INJECTION WITH

$\begin{array}{lccccc} & \text { Total } & \text { Labelled } & & \text { No. of cells } \\ & \text { cells } & \text { cells } & \text { Per cent } & \text { with hot } X^{\mathrm{t}} & \text { Per cent } \\ \text { Maternal } X^{\mathrm{t}} & 1,394 & 586 & 40 \cdot 6 & 38 & 2 \cdot 7 \\ \text { Paternal } X^{\mathrm{L}} & \mathbf{4 5 8} & \mathbf{2 3 1} & 50 \cdot 4 & 11 & 2 \cdot 4\end{array}$

It can be seen from Table 1 that the $X^{\mathrm{t}}$ was the latelabelling $X$ chromosome in approximately the same proportion of cells in both types of animal demonstrating that the origin of the $X$-chromosome (at least when both parents are of the same species) did not affect its chanee of being late-labelling.

Where it was possible to observe a hot chromosome other than the $X^{\mathrm{t}}$ (presumably the $X^{\mathrm{n}}$ ) with a fair degree of certainty these were recorded, but were found to occur in only 0.4 per cent and 0.1 per cent of cells for the maternal and paternal $X^{t}$ mice respectively. The low frequency of occurrence of such colls is thought to be an underestimate because of the difficulty of recognizing the $X^{n}$ chromosome. I do not suggest that the labelling of the two $X$ chromosomes is non-random.

Patorson Laboratories,

Ann C. Chandley

Christie Hospital,

Manchester.

Recived November 27, 1968.

${ }^{1}$ Evans, H. J., Ford, C. E., Lyon, M. F., Gray, J., Nature, 206, 900 (1965).

${ }^{2}$ Ohno, S., and Cattanach, B., Cytogenetics, 1, 129 (1962).

${ }^{8}$ Lyon, M. F., Nature, 190, 372 (1961).

4 Bianchi, N., Lima-de-Faria, A., and Jaworska, H., Hereditas, 51, 207 (1964).

\section{Banded Polytene Chromosomes in the Legume Phaseolus vulgaris}

GIANT chromosomes have recently been found in different cells in the ovule of some Angiosperms ${ }^{1-3}$. The homologues are not paired and they have a granular structure without distinct bands, thus differing from the characteristic salivary gland chromosomes of Chironomus or Drosophila. They are more comparable with the primary polytene chromosomes in the ovary of Calliphora ${ }^{4,5}$, or the salivary gland chromosomes of Dasyneura ${ }^{6}$. In Phaseolus coccineus the single giant chromosomes could only be identified in the suspensor cell nuclei, because of the uniformity of euchromatic and heterochromatic regions ${ }^{7-9}$. In the Diptera the appearance of distinct bands sometimes depends on a low breeding temperature $e^{410-12}$, and so we have investigated the influerice of temperature on the structure of giant chromosomes in the Angiosperm Phaseolus vulgaris, which is known to have giant chromosomes in the suspensor cell nuclei similar to those described for Phaseolus coccineus. The 